DOI: $10.34185 / 1991-7848.2019 .01 .07$

УДК 669.84.244.66

Л.С. Молчанов, А.Г. Чернятевич, В.В. Вакульчук, О.А. Чубіна

\title{
КОМПЛЕКСНИЙ ТЕХНІКО-ЕКОНОМІЧНИЙ АНАЛІЗ ВПЛИВУ КОНСТРУКЦІЇ ВЕРХНІХ ПРОДУВАЛЬНИХ ПРИСТРОЇВ НА ОСНОВНІ ПОКАЗНИКИ ВИРОБНИЦТВА СТАЛІ В КИСНЕВИХ КОНВЕРТЕРАХ
}

\begin{abstract}
У статті наведено результати розрахунково-аналітичної оцінки впливу конструкції верхнього продувального пристрою на основні техніко-економічні показники процесу виплавки сталі в кисневих конвертерах з донною подачею нейтрального газу. Проведення комплексної економічної оцінки базувалося на сумуванні відхилення відносних витрат виробництва, що пов'язані з забезпеченням виплавки залізовуглецевого напівпродукту (вартість основних шихтових матеріалів), без врахування вартості модернізації основного технологічного устаткування. За результатами проведених досліджень встановлено, що при використанні класичної конструкції верхньої кисневої фурми нижча

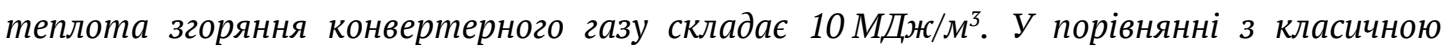
конструкцією двоярусна, двоконтурна та триярусна фурми забезпечують зниження нижчої теплоти згоряння конвертерного газу на 8,5, 4,4 та 27,1 \% відн. відповідно. При компенсації зниження теплоти згоряння димових газів за рахунок використання природного газу та врахування усіх основних параметрів технологічного процесу виплавки сталі економія складає 3,23 \$ США / т сталі для двоконтурної, 6,81 \$ США / т сталі - для двохярусної та 11,61 \$ США / т сталі - для трьохярусної конструкції фурм у порівнянні 3 використанням класичної конструкції.
\end{abstract}

Ключові слова: економічна оцінка, конструкція верхньої продувальної фурми, технікоекономічні показники, кисневий конвертер, вторинний енергетичний ресурс.

\section{Вступ}

В сучасних умовах металургійні підприємства $є$ однією з найбільш енерго- та ресурсовитратних ланок виробничо-промислового комплексу. Зважаючи на це в умовах більшості металургійних підприємств впроваджуються технологічні, організаційні та комплексні заходи щодо ефективної рециркуляції вторинних енергетичних ресурсів (ВЕР) в рамках виробничого циклу [1]. Здійснюється реконструкція трактів газовідведення кисневих конвертерів з переходом на роботу за системою «без допалювання», що дозволяє збирати конвертерний газ, який містить не менше $30 \%$ СО в газгольдери й проводити його підготовку до подальшого використання в якості палива. Виходячи із закордонного досвіду виробництва сталі [2], відомо що при отриманні 1 млн. т рідкої сталі утворюється близько 80 млн. м ${ }^{3}$

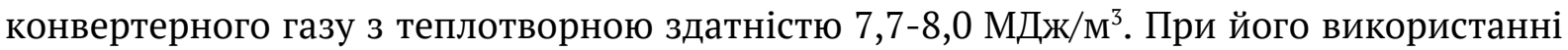
у якості газоподібного палива, він може замінити близько 16 млн. м $^{3}$ природного газу.

(c) Молчанов Л.С., Чернятевич А.Г., Вакульчук В.В., Чубіна О.А., 2019 


\section{Постановка мети і завдань дослідження}

Процес допалення $\mathrm{CO}$ до $\mathrm{CO}_{2}$ в порожнині конвертера 3 використанням двоярусної фурми є одним 3 найкращих способів поліпшення теплового балансу конвертерної плавки. Так при її використанні вдалося збільшити витрату брухту на 7\% i скоротити тривалість продувки на 22\%, знизити витрату вапна, вапняку та плавикового шпату [3]. Разом 3 тим через збільшену концентрацію $\mathrm{CO}_{2}$ в відпрацьованих газах знижується теплотворна здатність останнього, що необхідно враховувати при роботі конвертерів зі збором газу в газгольдер та подальшою підготовкою до утилізації.

Виходячи $з$ вище викладених матеріалів $є$ доцільним проведення економічної оцінки впливу різних конструкцій кисневих фурм і способів продувки конвертерної ванни $з$ допаленням димових газів на ефективність виробництва залізовуглецевого напівпродукту 3 урахуванням складу відпрацьованих газів, що поступають в газгольдер, з наступним застосуванням останніх в якості паливного ВЕР в умовах сучасного металургійного підприємства.

\section{Методика проведення досліджень}

Оцінка ефективності застосування багатоярусних кисневих фурм, що дозволяють підвищити технологічні і техніко-економічні показники конвертерної плавки в умовах зниження теплотворної здатності димових газів проводилася для умов виплавки стали в конвертерах комбінованої продувки з подачею кисню зверху та нейтрального газу через днище. В якості базової була прийнята класична технологія виплавки сталі із застосуванням верхньої багатосоплової кисневої фурми звичайної конструкції.

Проведення економічної оцінки [4] базувалася на підсумовуванні відхилення відносних витрат виробництва, пов'язаних із забезпеченням виплавки залізовуглецевого напівпродукту (вартість основних шихтових матеріалів), без урахування вартості модернізації основного технологічного обладнання та може бути розрахована відповідно до виразу:

$$
\Delta E=Ц\left(M_{i}^{\text {порів }}-M_{i}^{\text {баз }}\right), \$ \text { США / т сталі }
$$

де Ц - вартість шихтового материалу, \$ США / т (\$ США / $\left.\mathrm{M}^{3}\right) ; M_{i}^{\text {порів }}$ и $M_{i}^{\text {баз }}$ - витрата іго шихтового матеріалу для порівняльного способу виплавки сталі та базового, т / т сталі ( $\mathrm{M}^{3} /$ т сталі).

Оцінка витрат, пов'язаних зі зниженням теплотворної здатності конвертерного газу, що уловлюється, здійснювалася шляхом визначення кількості добавки до нього природного газу, необхідної для забезпечення теплоти згорання конвертерного газу на рівні базової технології конвертерної плавки. При цьому теплота згоряння газоподібного палива була визначена виходячи зі вмісту монооксиду вуглецю, водню та інших горючих складових у відповідності до виразу [5]: 


$$
Q_{H}^{c}=108 \cdot H_{2}+126,3 \cdot C O+358,2 \cdot \mathrm{CH}_{4}+560,5 \cdot C_{2} H_{2}+\ldots, \text { КДж/м }{ }^{3},
$$

де $\mathrm{H}_{2}, \mathrm{CO}, \mathrm{CH}_{4}, \mathrm{C}_{2} \mathrm{H}_{2}, \ldots$ - вміст окремих газових компонентів у складі газоподібного палива, \% об'ємний.

Розрахунок витрати природного газу здійснювали відповідно до виразу:

$$
V_{\text {n.z. }}=\frac{Q_{н \text { пор }}^{c}-Q_{\text {нбаз }}^{c}}{Q_{\text {н.г. }}^{c}}, \mathrm{M}^{3} \text { природ. газу } / \mathrm{M}^{3} \text { конвертер. газу, }
$$

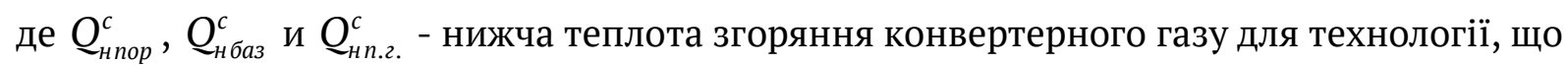
розглядається, базової та для природного газу, кДж/м³

Враховуючи особливості виплавки стали в кисневих конвертерах необхідно відзначити, що на склад відведених конвертерних газів значно впливає конструкція основних дуттєвих пристроїв для введення кисню в розплав [6]. На сучасному етапі розвитку конвертерного виробництва сталі найбільшого поширення набули фурми для верхньої подачі кисню наступних конструкцій: класична, двоконтурна, двоярусна i триярусна. Схеми організації комбінованої продувки конвертерної ванни 3 застосуванням зазначених конструкцій дуттєвих пристроїв представлені на рис. 1.

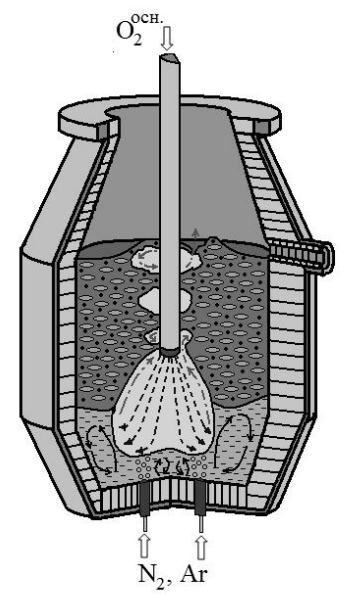

a)

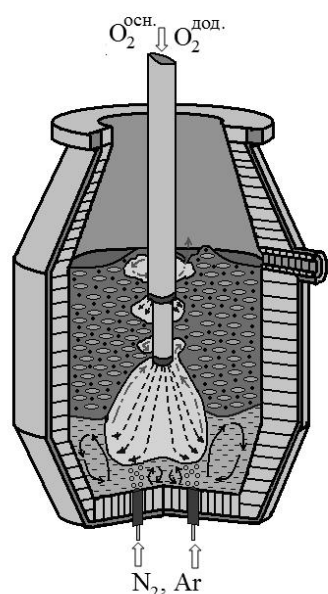

б)

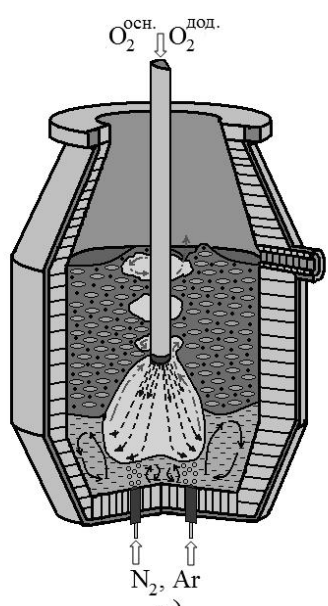

B)

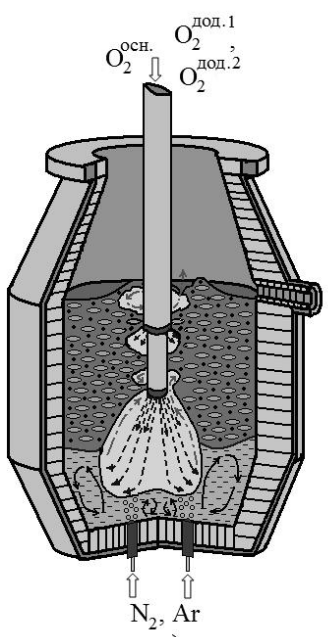

Г)

Молчанов Тавр Сергевич

Рисунок 1 - Схеми комбінованої продувки конвертерної ванни звуковими $\mathrm{i}$ понадзвуковими кисневими струменями при застосуванні фурм різної конструкції: а - класична; б - двоярусна; в - двоконтурна; г - триярусна

Для оцінки ефективності застосування звичайної і багатоярусних кисневих фурм в умовах комбінованої продувки конвертерної ванни (рис. 1) були використані технологічні показники плавок (табл. 1), проведених на 160-т конвертерах [7] та відомості про вартість основних шихтових матеріалів, що використовуються в конвертерній плавці (рис. 2). 
Технологічні показники виплавки сталі в 160-т конвертерах комбінованого дуття (кисень зверху, нейтральний газ знизу) із застосуванням кисневих фурм різної конструкції [7]

\begin{tabular}{|c|c|c|c|c|c|}
\hline \multirow{2}{*}{ № } & \multirow{2}{*}{ Показник } & \multicolumn{4}{|c|}{ Конструкція фурми } \\
\hline & & двоконтурна & двоярусна & класична & триярусна** \\
\hline 1. & Витрата чавуну, кг/т & 763,6 & 752,2 & 788,3 & 727,6 \\
\hline 2. & Витрата брухту, кг/т & 363,7 & 369,2 & 331,2 & 388,4 \\
\hline 3. & Витрата вапна, кг/т & 61,2 & 61,7 & 65,1 & 57,1 \\
\hline 4. & Витрата $\mathrm{CaF}_{2}, \mathrm{k} / \mathrm{T}$ & 2,3 & 1,7 & 2,45 & 1,5 \\
\hline 5. & Витрата антрациту, кг/т & 7,5 & 4,2 & 7,25 & 3,5 \\
\hline 6. & Витрата кисню, $\mathrm{M}^{3} / \mathrm{T}$ & 49 & 49,5 & 57,15 & 49,8 \\
\hline 7. & Вихід придатного, \% & 88,7 & 89,5 & 89,3 & 89,6 \\
\hline 9. & Витрата футерівки, кг/т & 2,443 & 2,359 & 2,177 & 2,294 \\
\hline 8. & $\begin{array}{l}\text { Кількість } \\
\text { газів }{ }^{*}, \mathrm{M}^{3} / \mathrm{T}\end{array}$ & 2,185 & 2,179 & 2,176 & 2,917 \\
\hline
\end{tabular}

* - оціночна величина відповідно до [8];

** - прогнозні дані, що базуються на результатах лабораторних досліджень

\section{Результати досліджень}

При обробці даних про склад газі, що відходять 3 конвертера, при комбінованій продувці [8] з урахуванням особливостей впливу конструкцій кисневих фурм на ступінь допалювання $\mathrm{CO}$ до $\mathrm{CO}_{2}$ [9-11] була отримана інформація про усереднений склад конвертерних газів, які збираються в газгольдер в інтервалі від 20 до 90 \% часу від початку продувки (табл. 2).

Таблиця 2

Усереднений склад зібраних в газгольдер конвертерних газів при комбінованій продувці з подачею кисню зверху через різні конструкції фурм та нейтрального газу через днище конвертера

\begin{tabular}{|l|l|l|l|l|l|l|}
\hline \multirow{2}{*}{ № } & \multirow{2}{*}{ Конструкція фурми } & \multicolumn{4}{l}{ Вміст сполук, \% за об’ємом } \\
\cline { 3 - 7 } & & $\mathrm{CO}$ & $\mathrm{CO}_{2}$ & $\mathrm{O}_{2}$ & $\mathrm{~N}_{2}$ & $\mathrm{H}_{2}$ \\
\hline 1. & Класична & 57,25 & 38,35 & 0,85 & 2,95 & 0,60 \\
\hline 2. & 2-х ярусна & 44,90 & 49,86 & 1,70 & 2,95 & 0,60 \\
\hline 3. & 2-х контурна & 50,99 & 44,10 & 1,36 & 2,95 & 0,60 \\
\hline 4. & 3-х ярусна & 38,57 & 56,18 & 1,70 & 2,95 & 0,60 \\
\hline
\end{tabular}

Розрахункові значення нижчої теплоти згоряння конвертерного газу, що відходить 3 робочого простору конвертера при застосуванні різних конструкцій кисневих фурм представлені на рис. 3. Відповідно до даних, представлених на ньому найвищу теплотою згоряння, на рівні 7,3 МДж/м³ при застосуванні верхньої продувальної фурми класичної конструкції. Це пов'язано 3 найбільшою концентрацією в димових газах монооксиду вуглецю. При аналізі впливу конструкції верхніх продувних пристроїв визначено, що з підвищенням ступеня допалювання $\mathrm{CO}$ до $\mathrm{CO}_{2}$ пропорційно знижується нижча теплота згоряння газів, що 
відходять. Таким чином, в порівнянні 3 класичною конструкцією верхньої продувальної фурми двоярусна, двоконтурна і триярусна фурми дозволяють досягти зниження нижчої теплоти згорання конвертерного газу, при всіх варіантах конвертерної плавки, на 21,4; 10,8 і 32,3\% відносних відповідно.

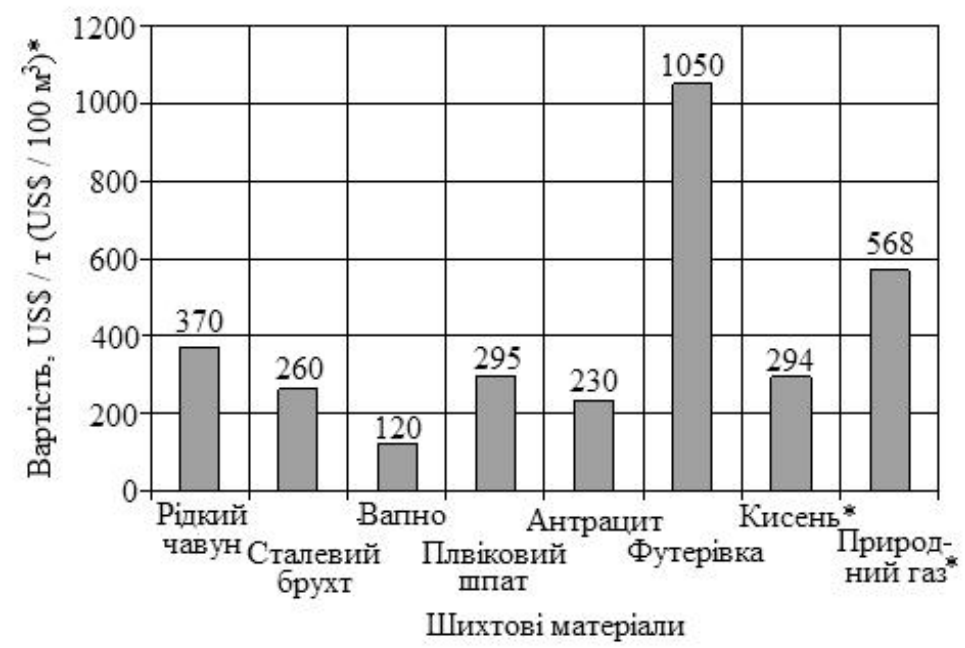

Рисеунок 2 - Середня вартість шихтових матеріалів, що застосовувалися в конвертерній плавці на українських підприємствах в 2014 р для циклу виробництва сталі, який передбачає виплавку чавуну без використання ПВП: цифри над стовпцями - ціна

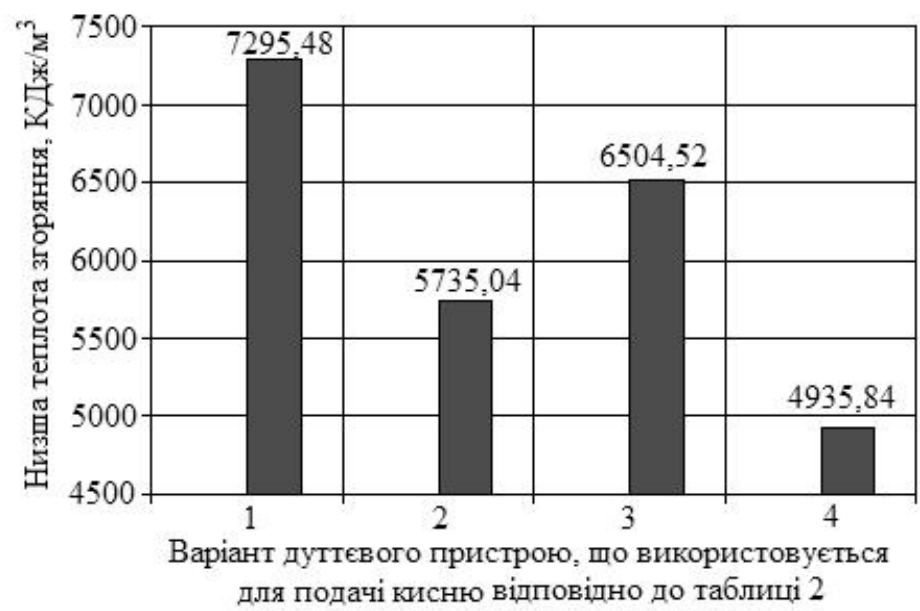

Рисунок 3 - Нижча теплота згоряння конвертерного газу, що утворюється при виробництві сталі в конвертерах 3 комбінованою продувкою при застосуванні різних конструкцій фурм:

цифри над стовпцями - чисельне значення нижчої теплоти згорання, кДж/ $\mathrm{m}^{3}$

Для встановлення ефективності застосування конвертерного газу в якості BEP необхідно порівняння нижчої теплоти його згоряння 3 аналогічними показниками газоподібних палив, що застосовуються. На сучасному етапі найбільшого поширення в металургійному виробництві знаходять такі види газоподібних палив: доменний газ, коксовий газ та природний газ. Їх усереднений хімічний склад представлений в табл. 3. 
Таблиця 3

Усереднений хімічний склад газоподібного палива, що застосовується в металургії [12]

\begin{tabular}{|c|c|c|c|c|c|c|}
\hline \multirow{2}{*}{ № } & \multirow{2}{*}{ Вид газоподібного палива } & \multicolumn{5}{|c|}{ Вміст компонентів, \% за об’ємом } \\
\hline & & $\mathrm{CO}$ & $\mathrm{CO}_{2}$ & $\mathrm{CH}_{4}$ & $\mathrm{H}_{2}$ & $\mathrm{~N}_{2}$ \\
\hline 1. & $\begin{array}{lrr}\text { Доменний } & \text { газ } \\
\text { виробництві } & \text { переробного } \\
\text { чавуну } & \\
\end{array}$ & 15,00 & 27,00 & 0,35 & 1,65 & 56,00 \\
\hline 2. & $\begin{array}{lr}\text { Доменний } & \text { газ } \\
\text { виробництві } & \text { при } \\
\text { чавуну } & \\
\end{array}$ & 11,00 & 30,00 & 0,35 & 2,25 & 56,40 \\
\hline 3. & $\begin{array}{lcc}\text { Доменний газ } & \text { при } \\
\text { виробництві феросплавів } & \end{array}$ & 6,00 & 33,00 & 0,35 & 3,75 & 56,90 \\
\hline 4. & Коксовий газ & 7,00 & 3,00 & 28,00 & 59,00 & 3,00 \\
\hline 5. & Природний газ* & - & 3,00 & 90,00 & 2,00 & 5,00 \\
\hline
\end{tabular}

* - склад природного газу взяти відповідно до джерела [13].

Розрахункові значення нижчої теплоти згоряння різних газоподібних палив, що застосовуються у металургії, представлені на рис. 4.

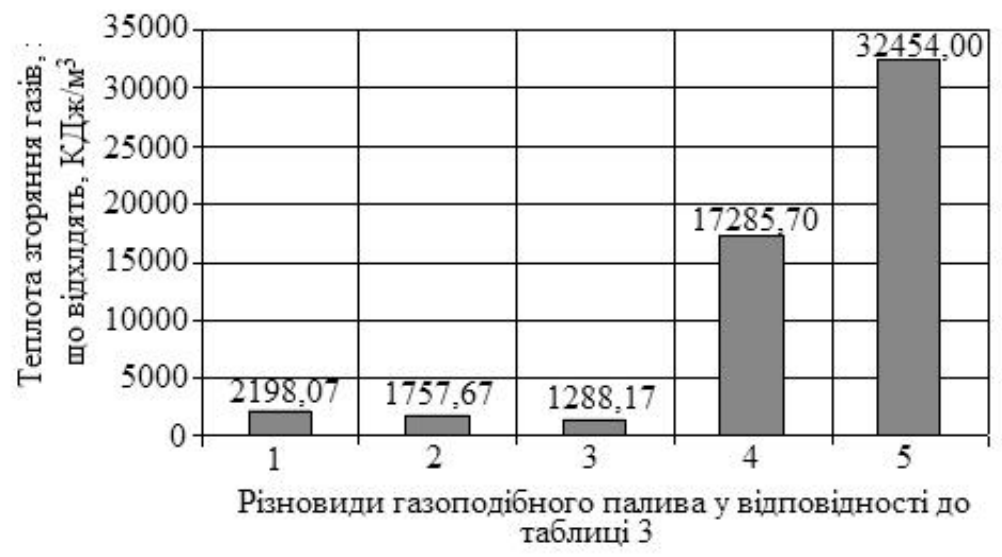

Рисунок 4 - Нижча теплота згоряння різних газоподібних палив, що застосовуються у металургії: цифри над стовпцями - чисельне

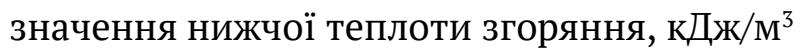

Як видно (рис. 4), найбільш калорійним паливом є природний газ, доменний газ має найбільш низьке значення нижчої теплоти згоряння, а коксовий газ займає проміжне положення між природним газом та доменним газом. У зв'язку з цим в технологічних процесах виробництва металопродукції найбільшого поширення набула коксо-доменна паливна суміш або суміш доменного газу і природним [14].

Співставлення даних (рис. 4) про нижчу теплоту згоряння конвертерного газу та інших газоподібних палив, що застосовуються у металургії, свідчить про необхідність застосування газоподібних продуктів конвертерної плавки в якості паливного ВЕР. Це пов'язано 3 тим, що нижча теплота згоряння конвертерного газу, зібраного в газгольдер при комбінованій продувці конвертерної ванни з використанням різних кисневих фурм, вище в порівнянні з доменним газом. 
Зниження нижчої теплоти згоряння конвертерного газу через допалення СО до $\mathrm{CO}_{2}$ в порожнині конвертера можна компенсувати добавкою до нього природного газу. Розрахунковий приріст витрат природного газу на компенсацію зниження теплоти згоряння конвертерних газів в разі заміни класичної конструкції фурми на двоярусну, двоконтурну і триярусну в конвертерах з комбінованою продувкою представлений на рис. 5. Так при заміні фурми класичної конструкції на двоярусну спостерігається приріст витрат природного газу 0,048 $\mathrm{m}^{3} / \mathrm{M}^{3}$ конвертерного газу, а при заміні на двоконтурну і триярусну 0,024 і 0,073 $\mathrm{m}^{3} / \mathrm{m}^{3}$ конвертерного газу відповідно.

Результати комплексного аналізу технологічної ефективності застосування дуттєвих пристроїв різної конструкції, що базується на оцінці витрат на забезпечення виробництва сталі, наведені на рис. 6. На підставі отриманих даних можна зробити висновок про ефективність застосування технології комбінованої продувки конвертерної ванни $з$ допалення газів, що відходять, в порожнині конвертера. Як видно, паралельно зі збільшенням частки $\mathrm{CO}_{2}$ в газах знижуються витрати на виробництво сталі.

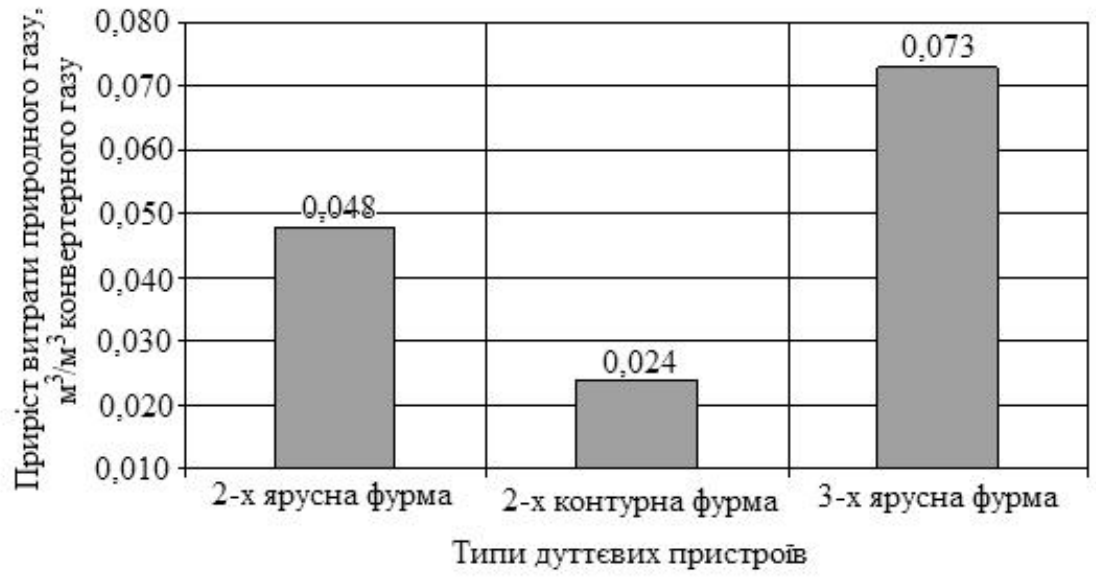

Рисунок 5 - Вплив заміни фурми класичної конструкції на приріст витрат природного газу для компенсації зниження теплоти згоряння конвертерних газів:

цифри над стовпцями - значення приросту витрати природного газу

У порівнянні із застосуванням фурм класичної конструкції чиста економія становлять 3,23 \$ США / т сталі для двоконтурної, 6,81 \$ США / т сталі - для двоярусної i 11,61 \$ США / т сталі - для триярусної. При цьому необхідно зазначити, що отримані результати є адекватними тільки для умов вітчизняного виробництва, коли вартість сталевого брухту нижче вартості рідкого переробного чавуну, що виплавляється в доменних печах без застосування пиловугільного палива. 


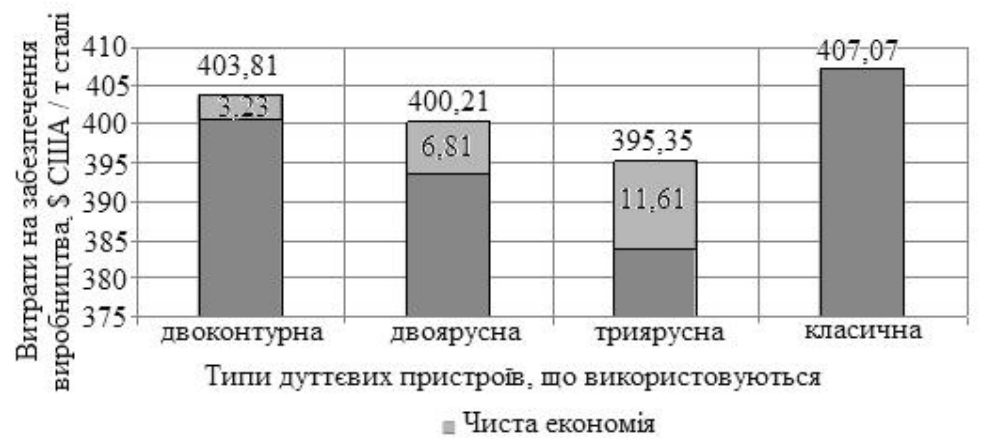

Рисунок 6 - Оцінка впливу конструкції дуттєвих пристроїв для подачі кисню на витрати забезпечення конвертерного виробництва сталі: цифри над кривими -

сумарні витрати; цифри на стовпцях - економія при виробництві сталі

\section{Висновки}

1. Розрахунково-аналітичним шляхом проведено оцінку впливу конструкцій кисневих фурм на нижчу теплоту згоряння конвертерних газів, що відходять, для умов комбінованої продувки конвертерної ванни з частковим допаленням $\mathrm{CO}$ до $\mathrm{CO}_{2}$ в порожнині конвертера.

2. Визначено, що при застосуванні класичної конструкції верхньої кисневої

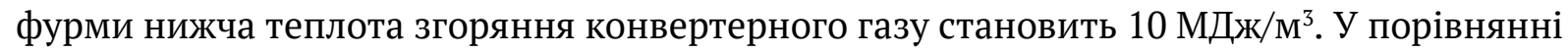
3 класичною конструкцією двоярусна, двоконтурна та триярусна фурми забезпечують зниження нижчої теплоти згоряння конвертерного газу на 8,5, 4,4 та 27,1\% відн. відповідно.

4. Підтверджено можливість застосування газоподібних продуктів конвертерної плавки в якості горючих ВЕР, що пов'язано з переважаючим значенням нижчої теплоти згоряння конвертерного газу в порівнянні з доменним газом.

5. Проведено комплексну економічну оцінку впровадження технологій 3 підвищення ступеня допалювання $\mathrm{CO}$ до $\mathrm{CO}_{2}$ в порожнині конвертера. Відповідно до неї визначено економічну ефективність даних заходів для кон'юнктурних умов вітчизняного металургійного виробництва.

\section{ЛITEPATУРА}

1. Бойченко Б.М., Охотский В.Б., Харлашин П.С. Конвертерне виробництво сталі: теорія, технологія, якість сталі, конструкції агрегатів, рециркуляція матеріалів i екологія: Підручник. - Дніпропетровськ: РВА «Дніпро-ВАЛ». - 2004. - 454c.

2. Рыжавский А.З., Пирогов А.Ю., Зимогляд А.В. Реконструкция газоотводящих трактов большегрузных конвертеров // Экология и промышленность.-2017.- № 3-4.C. $4-10$.

3. Работа 130-т конвертеров, оборудованных двухъярусными фурмами / В.И. Баптизманский, В.О. Куликов, А.Т. Китаев [и др.] // Экспресс-информация ЦНИИ и ТЭИ ЧМ.- 1974.- серия 6.- вып.-3.- С. 1-14.

4. Бойчик I.М. Економіка підприємства: навчальний посібник. - К.: Атіка, 2004. - 480с. 
5. ДСТУ 3581 - 97 «Енергозбереження. Методи вимірювання і розрахунку теплоти згоряння палива» - К.:Держстандарт України. - 1999. - 12с.

6. Бережинский А.И., Циммерман А.Ф. Охлаждение и очистка газов кислородных конвертеров. - М.: Металлургия. - 1983. - 272 с.

7. Комбинированная продувка металла с подачей нейтрального газа сверху и через днище конвертера / А.Г. Чернятевич, Р.С. Айзатулов, Л.М. Учитель [и др.] // Сталь.1989. - №5. -C. 20 - 23.

8. К вопросу повышения промышленной безопасности конвертеров и экологической безопасности процессов выплавки стали / Л.Г. Тубольцев, В.П. Корченко, В.Ф. Поляков [и др.] // Сборник научных трудов ИЧМ НАНУ «Фундаментальные и прикладные проблемы черной металлургии».-2011. - вып. 24. -С. 258-272

9. Высокотемпературное моделирование продувки конвертерной ванны с использованием двухъярусной кислородной фурмы / А.Г. Чернятевич, В.В. Вакульчук, Л.С. Молчанов [и др.] // Теория и практика металлургии.- 2017. - № 3-4. -С. 79 - 85.

10. Молчанов Л.С., Вакульчук В.В. Газодинамические особенности продувки конвертерной ванны через двухконтурную фурму // Инновационные пути модернизации базовых отраслей промышленности, энерго- и ресурсосбережение, охрана окружающей природной среды: сборник научных трудов VI Международной научно-практической конференции молодых ученых и специалистов, Харьков, 22 - 23 марта 2017 г. - Х.: ГП «УкрНТЦ «Энергосталь».-2017. - С. 102 - 108.

11. Термодинамическое и высокотемпературное моделирование комбинированной продувки конвертерной ванны с использованием трехъярусной кислородной фурмы / А.Г. Чернятевич, Л.С. Молчанов, П.О. Юшкевич, М.К. Чубин // Сборник научных трудов ИЧМ НАНУ «Фундаментальные и прикладные проблемы черной металлургии». 2017 - вып. №31. - С. 110 - 121.

12. Кривандин В.А., Егоров А.В. Тепловая работа и конструкция печей черной металлургии: Учебник для вузов. - М.: Металлургия, 1989. - 462с.

13. Ефименко Г.Г., Гиммельфарб А.А., Левченко В.Е .Металлургия чугуна - К.: Высшая школа. Главное издательство, 1981. - 496 с.

14. Губинский В.И. Металлургические печи: Учеб. пособие. - Днепропетровск: НМетАУ, 2006. - 85с.

\section{REFERENCES}

1. Boychenko B.M., Ohotskiy V.B., Harlashin P.S. Konverterne virobnitstvo stalI: teorlya, tehnologIya, yakIst stalI, konstruktsIYi agregatIv, retsirkulyatsIya materIalIv I ekologIya: PIdruchnik. - DnIpropetrovsk: RVA «DnIpro-VAL». - 2004. - 454s.

2. Ryizhavskiy A.Z., Pirogov A.Yu., Zimoglyad A.V. Rekonstruktsiya gazootvodyaschih traktov bolshegruznyih konverterov // Ekologiya i promyishlennost.-2017.- \# 3-4.-S. 4-10.

3. Rabota 130-t konverterov, oborudovannyih dvuh'yarusnyimi furmami / V.I. Baptizmanskiy, V.O. Kulikov, A.T. Kitaev [i dr.] // Ekspress-informatsiya TsNII i TEI ChM.- 1974.- seriya 6.- vyip.-3.- S. 1-14.

4. Boichyk I.M. Ekonomika pidpryiemstva: navchalnyi posibnyk. - K.: Atika, 2004. - 480c. 
5. DSTU 3581 - 97 «Enerhozberezhennia. Metody vymiriuvannia i rozrakhunku teploty zghoriannia palyva» - K.:Derzhstandart Ukrainy. - 1999. - 12s.5.

6. Berezhinskiy A.I., Tsimmerman A.F. Ohlazhdenie i ochistka gazov kislorodnyih konverterov. - M.: Metallurgiya. - 1983. - 272 s.

7. Kombinirovannaya produvka metalla s podachey neytralnogo gaza sverhu i cherez dnische konvertera / A.G. Chernyatevich, R.S. Ayzatulov, L.M. Uchitel [i dr] // Stal.- 1989. -\#5. S. $20-23$.

8. K voprosu povyisheniya promyishlennoy bezopasnosti konverterov i ekologicheskoy bezopasnosti protsessov vyiplavki stali / L.G. Tuboltsev, V.P. Korchenko, V.F. Polyakov [i dr] // Sbornik nauchnyih trudov IChM NANU «Fundamentalnyie i prikladnyie problemyi chernoy metallurgii».-2011. - vyip. 24. -S. 258-272

9. Vyisokotemperaturnoe modelirovanie produvki konverternoy vannyi s ispolzovaniem dvuh'yarusnoy kislorodnoy furmyi / A.G. Chernyatevich, V.V. Vakulchuk, L.S. Molchanov [i dr] // Teoriya i praktika metallurgii.- 2017. - \# 3-4. -S. 79 - 85.

10. Molchanov L.S., Vakulchuk V.V. Gazodinamicheskie osobennosti produvki konverternoy vannyi cherez dvuhkonturnuyu furmu // Innovatsionnyie puti modernizatsii bazovyih otrasley promyishlennosti, energo- i resursosberezhenie, ohrana okruzhayuschey prirodnoy sredyi: sbornik nauchnyih trudov VI Mezhdunarodnoy nauchno-prakticheskoy konferentsii molodyih uchenyih i spetsialistov, Harkov, 22 - 23 marta 2017 g. - H.: GP «UkrNTTs «Energostal».-2017. - S. 102 - 108.

11. Termodinamicheskoe i vyisokotemperaturnoe modelirovanie kombinirovannoy produvki konverternoy vannyi s ispolzovaniem treh'yarusnoy kislorodnoy furmyi / A.G. Chernyatevich, L.S. Molchanov, P.O. Yushkevich, M.K. Chubin // Sbornik nauchnyih trudov IChM NANU «Fundamentalnyie i prikladnyie problemyi chernoy metallurgii». 2017. - vyip. \#31. - S. 110 - 121.

12. Krivandin V.A., Egorov A.V. Teplovaya rabota i konstruktsiya pechey chernoy metallurgii: Uchebnik dlya vuzov. - M.: Metallurgiya, 1989. - 462s.

13. Efimenko G.G., Gimmelfarb A.A., Levchenko V.E .Metallurgiya chuguna - K.: Vyisshaya shkola. Glavnoe izdatelstvo, 1981. - 496 s.

14. Gubinskiy V.I. Metallurgicheskie pechi: Ucheb. posobie. - Dnepropetrovsk: NMetAU, 2006. $-85 \mathrm{~s}$.

Received 10.01.19

\section{COMPREHENSIVE TECHNICAL AND ECONOMIC ANALYSIS OF THE INFLUENCE OF THE DESIGN OF TOP BLOWING DEVICES ON THE MAIN INDICATORS OF STEEL PRODUCTION IN OXYGEN CONVERTERS}

The article presents the results of the analytical estimation of the impact of the design of the top blowing devices on the main technical and economic indicators of the steelmaking process in oxygen converters with bottom blowing with neutral gas. A comprehensive economic assessment was based on summing up the deviation of relative production costs for crude steel melting (the cost of basic charge materials), without taking into account the cost of upgrading the main process equipment. According to the results of the carried out research, it has been determined that application of the classical design of the oxygen lance, 
the net calorific value of the converter gas is $10 \mathrm{MJ} / \mathrm{m} 3$. In comparison with the classical design, the two-tier, two-circuit and three-tier lances ensure a reduction in the net calorific value of the converter gas by $8.5,4.4$ and $27.1 \%$ rel. respectively. When compensating for reducing the net calorific value of exhaust gases with natural gas and taking into account all the main parameters of the steelmaking process, the savings amount to $\$ 3.23$ / ton of steel for two-circuit, \$ 6.81 / ton of steel for two-circuit and $11.61 \$ /$ ton steel - for the three-tier lances, compared with the use of the classical design.

Keywords: economic assessment, design of the top blowing lance, technical and economic indicators, oxygen converter, secondary energy resource.

\section{КОМПЛЕКСНЫЙ ТЕХНИКО-ЭКОНОМИЧЕСКИЙ АНАЛИЗ ВЛИЯНИЯ КОНСТРУКЦИИ ВЕРХНИХ ПРОДУВОЧНЫХ УСТРОЙСТВ НА ОСНОВНЫЕ ПОКАЗАТЕЛИ ПРОИЗВОДСТВА СТАЛИ В КИСЛОРОДНЫХ КОНВЕРТЕРАХ}

В статье расчетно-аналитическим путем проведена оценка влияния конструкций кислородных фурм на низшую теплоту сгорания отходящих конвертерных газов для условий комбинированной продувки конвертерной ванны с частичным дожига СО до CO2 в полости конвертера. Подтверждена возможность применения газообразных продуктов конвертерной плавки в качестве горючих ВЭР, что связано с преобладающим значением низшей теплоты сгорания конвертерного газа по сравнению с доменным газом.

Ключевые слова: экономическая оценка, конструкция верхней продувочной фурмы, технико-экономические показатели, кислородный конвертер, вторичный энергетический ресурс.

Молчанов Лавр Сергійович - к.т.н., старший науковий співробітник відділу фізико-технічних проблем металургії сталі, Інститут чорної металургії ім. 3.І. Некрасова НАН Українию.

Molchanov Lavr Serhiiovych - Cand. of Sci. (Tech.), Senior Researcher of the Department of Physical and Technical Problems of Metallurgy, Institute of Ferrous Metallurgy, named Z.I. Nekrasova NASU.

Чернятевич Анатолій Григорович - д.т.н., проф., завідувач відділу фізикотехнічних проблем металургії сталі, Інститут чорної металургії ім. 3.І. Некрасова НАН України.

Cherniatevych Anatolii Gryhorovych - Doc. of Sci. (Tech.), Prof., Head of the Department of Physical and Technical Problems of Metallurgy, Institute of Ferrous Metallurgy, named Z.I. Nekrasova NASU.

Вакульчук Володимир Вікторович - молодший науковий співробітник відділу фізико-технічних проблем металургії сталі, Інститут чорної металургії ім. 3.I. Некрасова НАН України.

Vakulchuk Volodymyr Viktorovych - Junior Researcher of the Department of Physical and Technical Problems of Metallurgy, Institute of Ferrous Metallurgy, named Z.I. Nekrasova NASU.

Чубіна Олена Анатоліївна - к.т.н., доц., доцент кафедри металургії чорних металів, Дніпровський державний технічний університет.

Chubina Olena Anatoliivna - Cand. of Sci. (Tech.), Docent, Assistant professor of the Department of Metallurgy of Ferrous Metals, Dniprovsky State Technical University. 